\title{
Secondary data analyses of dietary surveys undertaken in South Africa to determine usual food consumption of the population
}

\author{
Nelia Patricia Steyn ${ }^{1, *}$, Johanna Helena $\mathrm{Nel}^{2}$ and Annette Casey ${ }^{3}$ \\ ${ }^{1}$ Chronic Diseases of Lifestyle Unit, South African Medical Research Council, PO Box 19070, Tygerberg, \\ Cape Town 7505, South Africa: ${ }^{2}$ Chesham House, Hermanus, Western Cape, South Africa: ${ }^{3}$ Directorate Food \\ Control, Department of Health, Pretoria, South Africa
}

Submitted 29 January 2003: Accepted 30 April 2003

\begin{abstract}
Objective: The primary objective of this study was to generate a reference table of food items and average amounts of these items consumed by South Africans, for the Department of Health. The reference table was required to be representative of foods and beverages eaten frequently by children and adults from all age and ethnic groups in order for the Department of Health to test for contaminants in these foods.

Design: The National Food Consumption Survey (NFCS) served as a framework for compiling data on children since this was a national representative survey of 1-9-year-old children undertaken in South Africa in 1999. However, there has never been a national dietary survey on adults in South Africa. Consequently the data had to be extrapolated from existing isolated surveys on adults. Secondary data analysis was conducted on existing dietary databases (raw data) obtained from surveys undertaken on adults in South Africa between 1983 and 2000. Available datasets were regional and independent, and were not individually representative of the South African diet. It was therefore necessary to use different statistical methods, including factor analyses, weighting and correlations, to generate ethnic and geographic representative data for adults. Two methods were used: Method 1, which corresponded with results of the NFCS (over-sampled for low socio-economic status), and Method 2, which was based on ethnic proportions of the population. Results: The secondary data analyses generated food items most commonly consumed by the South African adult population (Method 1) in descending frequency of usage and average (mean) amount per day: maize porridge (78\%/848 g), white sugar $(77 \% / 27 \mathrm{~g})$, tea $(68 \% / 456 \mathrm{~g})$, brown bread $(55 \% / 165 \mathrm{~g})$, white bread (28\%/163 g), non-dairy creamer $(25 \% / 6 \mathrm{~g})$, brick margarine $(21 \% / 19 \mathrm{~g})$, chicken meat $(19 \% / 111 \mathrm{~g})$, full-cream milk (19\%/204 g) and green leaves (17\%/182 g). In 6-9-yearolds, maize porridge $(72 \% / 426 \mathrm{~g})$, sugar $(76 \% / 23 \mathrm{~g})$, tea $(51 \% / 258 \mathrm{~g})$, full-cream milk $(35 \% / 171 \mathrm{~g})$ and white bread $(33 \% / 119 \mathrm{~g})$ were eaten most frequently. Similarly, in $1-5$-year-olds, the foods consumed most frequently were maize porridge $(80 \% / 426 \mathrm{~g})$, sugar $(76 \% / 21 \mathrm{~g})$, tea $(44 \% / 224 \mathrm{~g})$, full-cream milk $(39 \% / 186 \mathrm{~g})$ and white bread $(24 \% / 83 \mathrm{~g})$. In order to evaluate the validity of the adult data generated, kilojoule values of the individual food items (per capita) were compared with food balance sheets (FBSs). The comparison was favourable except that the FBSs had a higher overall energy intake per capita of between 22 and $28 \%$.

Conclusion: Reference tables of commonly consumed foods and beverages were generated at minimal cost based on secondary data analyses of past dietary surveys in different South African populations.
\end{abstract}

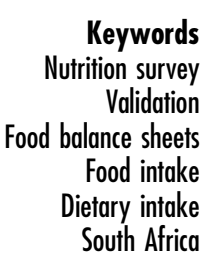

The Food and Agriculture Organization (FAO), the World Health Organization (WHO) and the United Nations Environment Programme have jointly developed guidelines for the determination of chemical contaminants in foods and beverages ${ }^{1-3}$. These guidelines provide detailed procedures and methods by which such studies should be conducted in order to ascertain whether consumers are at risk from chemical contaminants found in the foods they consume. Since South Africa is one of the Codex Alimentarius Member Countries, it is required to undertake an analysis of contaminants in the national food supply on a regular basis. To do this, the Department of 
Health (DOH) needs to know which items, and the average portion size, are eaten by the majority of the population.

Three practical approaches to determine amounts of contaminants from dietary intake studies have been recommended, namely: (1) the total diet study method; (2) selective studies of individual foodstuffs; and (3) duplicate portion studies. Since the WHO/FAO has recommended use of the 'total diet study' approach, which focuses on food and beverage consumption of the general population, this method was selected for the current study ${ }^{2,4,5}$.

To measure contaminants in food it is necessary to know what the main dietary sources are. This ideally entails the undertaking of a dietary survey on a nationally representative sample in order to determine which foods items are consumed by at least $97.5 \%$ of the population. Since this is a very costly undertaking, the DOH decided to utilise data on adults from dietary surveys undertaken from 1983 to 2000. The National Food Consumption Survey (NFCS) ${ }^{6}$, which was undertaken in 1999, served as a source of nationally representative data on children.

The primary objective of this study was to generate a reference table of food items and average (mean) portion sizes consumed by South Africans for the DOH. The reference table was required to be representative of items eaten by children and adults from the major ethnic groups (black and white) found in nine provinces. Since the majority (77\%) of the population is black, it is important to note that the final food items generated mostly reflect the 'typical' diet consumed by black South Africans. The DOH will subsequently undertake analyses of items in the reference table and contaminant exposure doses will be calculated for the population by multiplying the average (mean) food intake by substance concentrations to determine average daily dose per contaminant. Evaluation of risk will be determined by comparison of exposure doses with exposure limits according to the Acceptable Daily Intakes (ADIs), Theoretical Maximum Daily Intakes (TMDIs) and Codex Maximum Residue Limits (MRLs) ${ }^{2,4,5}$.

\section{Methods and materials}

\section{Dietary survey databases utilised in development of the food tables}

The first phase of this study involved an evaluation of available databases. These were obtained by the $\mathrm{DOH}$ from the original sources (organisations/authors). The NFCS provided a database on dietary intakes of children aged 1-9 years. Data on adults were integrated from eight different studies (one unpublished) undertaken in different provinces and ethnic groups ${ }^{6-32}$. The national food balance sheets (FBSs) ${ }^{33}$ and data from an isolated study on water consumption ${ }^{34}$ were also included. Most databases were available on Excel spreadsheets and were subsequently analysed using the SAS System for Windows,
Release 8.02 (SAS Institute Inc., Cary, NC, USA, 2001). Table 1 presents a description of the studies utilised and their dietary methodologies. Since two different methods were used (24-hour recall* and frequency method + ), the data were kept in the two separate categories and analysed separately. Since all of the databases (24-hour and frequency) were used to compare the mean consumption of adolescents and adults, the 'frequency' databases are also shown in Table 1 . However, only results using 24-hour recalls are reported here. Results of the frequency databases are published elsewhere ${ }^{36}$.

\section{Structuring of existing dietary databases}

Step 1: Standardisation of food codes in all dietary databases

The dietary databases used in this study made use of the Medical Research Council Food Composition Tables and software ${ }^{37,38}$. These tables were updated in 1999 and many of the food codes were changed ${ }^{38}$. Hence it was necessary to first ensure that all databases conformed to the updated food codes.

Step 2: Aggregation of information on food

The $\mathrm{WHO}^{5}$ provides three lists of analyses and commodities that should be monitored by member countries of the Codex Alimentarius: a core list (for developing countries), an intermediate list (for countries with some industrial development) and a comprehensive list (for developed countries). Because of the availability of the NFCS data, which comprises a nationally representative sample ${ }^{6}$, and other appropriate surveys, this study focused on providing tables according to the comprehensive list. In order to compile comprehensive tables, aggregation of food items was done at three levels.

- Level 1. Foods and beverages contained in the South African food composition tables ${ }^{37}$ were first classified into food categories according to the GEMS/Food (Global Environmental Monitoring System/Food Contamination Monitoring and Assessment Programme) commodities of the $\mathrm{WHO}^{3}$. The GEMS/Food categories include the following main groups: cereals; sugars and honey; nuts and oilseeds; vegetable oils and fats; stimulants; spices; pulses; roots and tubers; vegetables; fish and seafood; eggs; fruit; milk and milk products; meat and offal; animal oils and fats. Since there were no GEMS/Food codes for some food commodities, new groups were created for alcoholic beverages, infant

*The 24-hour recall method requires participants to recall all food and beverages consumed during the previous $24 \mathrm{~h}$. It is a reflection of current dietary consumption. A limitation of this method is that it is inclined to underreport dietary intake.

tThe quantified food frequency method requires participants to recall average amounts of food consumed on a daily, weekly or monthly basis. It is a reflection of a longer period of consumption. A limitation of this method is that it is known to overreport dietary intakes $^{35}$. 
Table 1 Summary of the databases and dietary methods used in the present study

\begin{tabular}{|c|c|c|c|c|c|}
\hline $\begin{array}{l}\text { Database* }^{*} \\
\text { (dietary method } \dagger \text { ) }\end{array}$ & $\begin{array}{l}\text { Ethnic } \\
\text { group }\end{array}$ & Area & Groups & Age in years: $(n)$ & Publications \\
\hline $\begin{array}{l}\text { NFCS (24HR and } \\
\text { FFREQ) }\end{array}$ & All & South Africa & $\begin{array}{l}\text { Pre-school \& } \\
\text { primary }\end{array}$ & $\begin{array}{l}1-9: n=2868 \ddagger \\
1-5: n=2051 \\
6-9: n=817\end{array}$ & Labadarios et al., $2000^{6}$ \\
\hline $\begin{array}{l}\text { Lebowa Study } \\
(24 \mathrm{HR})\end{array}$ & Black & $\begin{array}{l}\text { Northern Province, } \\
\text { rural }\end{array}$ & $\begin{array}{l}\text { Pre-school, } \\
\text { primary school \& } \\
\text { secondary school }\end{array}$ & $\begin{aligned} 1-25: & n=483 \ddagger \\
1-5: & n=118 \\
6-9: & =73 \\
10+: & n=292 \\
10-13: & n=187 \\
14-18: & n=75 \\
19-25: & n=30\end{aligned}$ & $\begin{array}{l}\text { Steyn et al., } 1992^{7} ; \\
\text { Steyn et al., 1993 } \\
\text { Badenhorst et al., } 1993^{10}\end{array}$ \\
\hline $\begin{array}{l}\text { Dikgale Study } \\
(24 \mathrm{HR})\end{array}$ & Black & $\begin{array}{l}\text { Northern Province, } \\
\text { rural }\end{array}$ & $\begin{array}{l}\text { Adults } \\
\text { (19 years } \\
\text { and above) }\end{array}$ & $\begin{array}{c}n=111 \text { with age available, } \\
209 \text { in total } \\
19-24: n=2 \\
25-39: n=33 \\
40-59: n=38 \\
60+: n=38\end{array}$ & $\begin{array}{l}\text { Steyn et al., } 1998^{11} \text {; } \\
\text { Steyn et al., } 2001^{12,13}\end{array}$ \\
\hline BRISK (24HR) & Black & $\begin{array}{l}\text { Western Cape, } \\
\text { urban }\end{array}$ & Children \& adults & $\begin{aligned} 3-99: & n=1507 \ddagger \\
1-5: & n=127 \\
6-9: & n=137 \\
10+: & n=1243 \\
10-13: & n=133 \\
14-18: & n=146 \\
19-24: & n=199 \\
25-39: & n=372 \\
40-59: & n=245 \\
60+: & n=148\end{aligned}$ & $\begin{array}{l}\text { Bourne et al., } 1993^{14} \\
\text { Bourne et al., } 1994^{15,16}\end{array}$ \\
\hline $\begin{array}{l}\text { THUSA } \\
\text { (FFREQ) }\end{array}$ & Black & $\begin{array}{l}\text { North West Province, } \\
\text { urban \& rural }\end{array}$ & Adults & $\begin{aligned} 18+: & n=890 \ddagger \\
14-18: n & =81 \\
19-24: & n=137 \\
25-39: & n=318 \\
40-59: & n=302 \\
60+: & n=52\end{aligned}$ & $\begin{array}{l}\text { Venter et al., } 2000^{17} ; \\
\text { Vorster et al., } 2000^{18} ; \\
\text { Maclntyre et al., } 2000^{19-21} \text {; } \\
\text { Maclntyre et al., } 2002^{22}\end{array}$ \\
\hline $\begin{array}{l}\text { THUSA Bana } \\
(24 \mathrm{HR})\end{array}$ & All & $\begin{array}{l}\text { North West Province, } \\
\text { urban \& rural }\end{array}$ & Children & $\begin{aligned} \text { All: } n & =1257 \ddagger \\
6-9: & n=6 \\
10-13: & n=868 \\
14-18: & n=383\end{aligned}$ & $\begin{array}{l}\text { Underhay et al., } 2001^{23} \text {; } \\
\text { Kruger et al., } 2002^{24}\end{array}$ \\
\hline $\begin{array}{l}\text { FYFS Project } \\
\text { (FFREQ) }\end{array}$ & Black & $\begin{array}{l}\text { Northern Province, } \\
\text { Gauteng, urban \& rural }\end{array}$ & $\begin{array}{l}\text { Adult } \\
\text { females }\end{array}$ & $\begin{aligned} 18-34: & n=136 \ddagger \\
\leq 18: & n=52 \\
19-24: & n=63 \\
\geq 25: & n=21\end{aligned}$ & $\begin{array}{l}\text { Steyn et al., } 2000^{25,26} \\
\text { Senekal et al., } 2001^{27}\end{array}$ \\
\hline $\begin{array}{l}\text { WRFS } \\
\text { (FFREQ) }\end{array}$ & All & South Africa & Adults & $\begin{aligned} 18+ & : n=449 \ddagger \\
<25: & n=43 \\
25-34: & n=124 \\
35-44: & n=117 \\
45-54: & n=93 \\
55-64: & n=61 \\
65+: & n=9\end{aligned}$ & $\begin{array}{l}\text { Senekal and Steyn, } 1997^{28} \text {; } \\
\text { Senekal et al., } 2003^{29}\end{array}$ \\
\hline CORIS (24HR) & White & $\begin{array}{l}\text { Western Cape, } \\
\text { urban \& rural }\end{array}$ & $\begin{array}{l}\text { Adults } \\
\text { (15 years } \\
\text { and above) }\end{array}$ & $\begin{aligned} 15-99: & n=1784 \mp \\
14-18: & n=281 \\
19-24: & n=127 \\
25-39: & n=463 \\
40-59: & n=686 \\
60+: & n=227\end{aligned}$ & $\begin{array}{l}\text { Wolmarans et al., } 1989^{30} \text {; } \\
\text { Steyn et al., } 1989^{31} ; \\
\text { Steyn et al., } 1997^{32} ; \\
\text { Wolmarans (unpublished } \\
\text { dietary data) }\end{array}$ \\
\hline $\begin{array}{l}\text { SA Food } \\
\text { Balance Sheets }\end{array}$ & All & South Africa & All & All & $\begin{array}{l}\text { Steyn et al., } 2001^{33} \text {; } \\
\text { Department of Agricultural } \\
\text { Statistics }\end{array}$ \\
\hline Water estimates & $\begin{array}{l}\text { White \& } \\
\text { coloured }\end{array}$ & $\begin{array}{l}\text { Greater } \\
\text { Cape Town }\end{array}$ & All & As for BRISK & Bourne, $1986^{34}$ \\
\hline
\end{tabular}

* Database: NFCS - National Food Consumption Survey; BRISK - Black Risk Factor Study; THUSA - Transition, Health and Urbanisation Study; THUSA Bana - Transition, Health and Urbanisation Study in Children; FYFS - First Year Female Students; WRFS - Weight and Risk Factor Study; CORIS Coronary Risk Factor Study; SA - South Africa.

† Dietary method: 24HR - 24-hour recall; FFREQ - food frequency.

$\ddagger$ Data are given for the total group first, followed by corresponding values for subgroups. 
foods, breast milk and breast milk substitutes, dietary supplements and soup mixes. This was done because these groups represent important commodities in the total South African diet.

- Level 2. Certain main groups were further sub-divided into smaller groups. For example, cereals were subdivided into maize, wheat, oats, barley, sorghum, rye and rice products. Fruit, vegetables, meat and offal were also sub-divided further.

- Level 3. This step involved grouping items of consumption within the GEMS/Food subgroups. This involved aggregating (grouping) foods that were similar in kind but were consumed in smaller amounts. Re-coding all food items into the Eurocodes made this possible since the Eurocodes provided more detail within food subgroups ${ }^{39}$.

- Level 4. Lastly, food items were also classified according to method of processing. Due to the relative importance of processing methods in determining levels of contaminants, foods and beverages were further categorised according to processing methods ${ }^{2}$ : fresh, canned, smoked, raw, dried, juice, pickled and frozen.

The preceding steps were taken to develop a new database comprising 1535 food items, originally created in the food composition tables ${ }^{37}$. Each food item now comprised a national (SA) food composition code and description; a GEMS/Food main group code $^{3}$; a GEMS/ Food subgroup code ${ }^{3}$; a detailed item code (Eurocode) ${ }^{39}$; and a description of processing when appropriate (i.e. dried/canned/fresh). Examples of the food groups are presented in Table 2 .

The final tables generated comprised the following data with regard to food items consumed: main food group (e.g. cereals); the subgroup where appropriate (e.g. maize); a description of the item where appropriate (e.g. maize porridge); the percentage of the sample consuming that item; the portion consumed per day by those individuals who actually consumed the item (average/mean portion); and the per capita amount consumed per day by all individuals in the relevant sample. The latter portion is smaller because it represents the total quantity consumed divided by the size of the relevant sample.

\section{Selection of age groups}

The $\mathrm{WHO}^{5}$ has recommended that where specific national or regional consumption data are available for different population subgroups (e.g. toddlers and infants), exposure assessments should be carried out for these groups. Using these recommendations as guidelines, all tables generated in the present study included the following age groups: pre-school - age $1-5$ years (1.00-5.99 years); schoolchildren - age 6-9 years (6.00-9.99 years); adolescents and adults - age 10+ years (sometimes referred to as 'adults').

The reason for selecting these age groups was based on the fact that the largest dietary database (NFCS) in South
Africa $^{6}$ included children aged $1-9$ years. The NFCS data were available in two age groups ( $1-5$ years and 6-9 years), for each of nine provinces of South Africa, and in urban or rural format. Vulnerable groups such as pregnant women and the elderly could not be determined since no (or very little) data were available on these groups.

The rationale for treating age $10+$ as a unit (and calling it an adult group) was the finding that the average consumption of adolescents (10-15 years) did not differ significantly from that of adults. Table 3 presents comparisons of mean energy intakes of the different age groups to substantiate this.

After careful consideration of the available databases, and after a comparison of data obtained by the food frequency and 24-hour recall methods of the NFCS, it was decided to keep data generated by the two methods apart and to analyse them separately. This was due to the following findings: (1) the average quantities consumed per food item were greater when the food frequency method was used; (2) a greater variety of items was consumed when using the food frequency method versus the 24-hour recall method (72 items vs. 16 items); and (3) the percentage of the group consuming a specific item was generally greater when the food frequency questionnaire was used.

It is important to evaluate the results of this paper in the context of the databases used. The estimates generated represent crude portions of food items consumed and should not be compared with the methods generally used in dietary surveys to evaluate macro- and micronutrient intakes of specific age groups. Although an attempt was made to include as many databases as possible to represent the average South African population, it was not realistic or feasible to include every study that had been undertaken in the specified period.

\section{Generation of adult data}

First, data from the NFCS were correlated with data from individual surveys on adults. Pearson correlation coefficients were calculated using both per capita portion size and percentage of the sample consuming the food item, using all items and subgroups consumed. An example of this is shown in Table 4. These analyses showed significant relationships (and correspondence) between children aged 1-5 and 6-9 years in the NFCS and the 1-5- and 6-9-year-olds of studies using the 24-hour recall method. Then NFCS 6-9-year-olds were correlated with $10+$-year-olds in the 24-hour recall studies, namely the Black Risk Factor Study (BRISK), the Lebowa Study, the Coronary Risk Factor Study (CORIS) and the Dikgale Study (note: Lebowa and Dikgale are place names). Correlation coefficients varied between 0.7 and 0.9, and all were significant at the 99\% level of confidence. 
Table 2 Example of the final food item database with its various aggregates

\begin{tabular}{|c|c|c|c|}
\hline $\begin{array}{l}\text { GEMS/Food } \\
\text { main group }\end{array}$ & $\begin{array}{l}\text { GEMS/Food } \\
\text { subgroup }\end{array}$ & $\begin{array}{l}\text { Combination } \\
\text { of codes }\end{array}$ & Description of food item \\
\hline \multirow[t]{3}{*}{ Cereals } & \multicolumn{3}{|c|}{$\begin{array}{l}\text { Combined GEMS/Food code with Eurocode. The purpose was to distinguish between milled and grain products, } \\
\text { breakfast cereals, snacks, breads and confectionery }\end{array}$} \\
\hline & MAIZE & $\begin{array}{l}\text { CF } 125506.18 \\
\text { CF } 125506.19 \\
\text { CF } 125506.70 \\
\text { CF } 125512.65 \\
\text { GC } 64506.18 \\
\text { GC } 65612.65\end{array}$ & $\begin{array}{l}\text { MAIZE PORRIDGE \& DISHES } \\
\text { CUSTARD POWDER, CORN STARCH } \\
\text { BREAKFAST CEREALS, MAIZE-BASED, CORN FLAKES, PUFFED CORN, ETC. } \\
\text { MAIZE-BASED SNACKS - NIKNAKS, CHIPNIKS } \\
\text { MAIZE SAMP/RICE \& DISHES } \\
\text { POPCORN }\end{array}$ \\
\hline & WHEAT & $\begin{array}{l}\text { CF } 121006.10 \\
\text { CF } 121106.10 \\
\text { CF } 121106.40 \\
\text { CF } 121106.44 \\
\text { CF } 121106.48 \\
\text { CF } 121106.50 \\
\text { CF } 121106.60 \\
\text { CF } 121106.70 \\
\text { CF } 121206.30 \\
\text { CP } 1211 P \\
\text { CP } 1212 P \\
\text { GC 654P } 06.10\end{array}$ & $\begin{array}{l}\text { TASTEE WHEAT, WHEAT GERM, SEMOLINA } \\
\text { WHEAT FLOURS } \\
\text { ROTI } \\
\text { MATZOS, CRACKERS, PROVITA } \\
\text { RUSKS } \\
\text { COOKIES, LOAVES, PANCAKES, TARTS, CAKES, PUDDING } \\
\text { SAMOOSA, VETKOEK, CHILLI BITES, SAVOURY TARTS } \\
\text { WHEAT-BASED CEREALS - ALL BRAN, WEETBIX, PUFFED WHEAT } \\
\text { PASTA \& NOODLE DISHES } \\
\text { WHITE BREAD/ROLLS } \\
\text { BROWN BREAD/ROLLS } \\
\text { CRUSHED \& PEARL WHEAT }\end{array}$ \\
\hline \multirow[t]{3}{*}{ Fish } & \multicolumn{3}{|c|}{$\begin{array}{l}\text { Combined GEMS/Food code with processing method. Overall consumption of fish was too little to distinguish food items } \\
\text { in more detail }\end{array}$} \\
\hline & CRUST & WC $143 \mathrm{CF}$ & CRUSTACEANS (CRAB, LOBSTER, MUSSELS, OYSTERS), COOKED \\
\hline & $\mathrm{FISH}$ & $\begin{array}{l}\text { WF } 115 \text { CF } \\
\text { WS } 125 \text { CF } \\
\text { WS } 125 \mathrm{CZ} \\
\text { WS } 125 P \text { CA } \\
\text { WS } 125 \mathrm{P} \mathrm{CF} \\
\text { WS } 125 \mathrm{P} \text { SM }\end{array}$ & $\begin{array}{l}\text { FISH, FRESHWATER, COOKED } \\
\text { FISH - SEA, COOKED, FRESH } \\
\text { FISH - SEA, FROZEN, COOKED } \\
\text { FISH - SEA, CANNED } \\
\text { FISH PASTE } \\
\text { FISH - SEA, SMOKED }\end{array}$ \\
\hline
\end{tabular}

GEMS/Food - Global Environment Monitoring System/Food Contamination Monitoring and Assessment Programme.

Second, relationships between databases were explored by means of factor analyses. This was done to determine whether the adult databases would follow a similar trend to the NFCS as for the 'step' on correlations, and also to determine whether it was possible to combine data from provinces when trying to estimate adult consumption. Factor analyses were done to establish the relationship between NFCS 6-9-year-olds in the nine provinces of South Africa, urban and rural separately, with those databases having adult participants, namely BRISK, the Lebowa Study, CORIS urban and rural (adults), the Dikgale Study (adults) and the Transition, Health and Urbanisation Study (THUSA) in children (THUSA Bana; urban and rural). Observations used in this process consisted of the different GEMS/Food subgroups consumed.

The results showed that factor 1 reflected portion size and factor 2 reflected variety of items consumed. Dikgale and Lebowa data clustered together with most NFCS rural groups to form a group (group 1). CORIS, BRISK and the Western Cape NFCS data clustered together (group 2). Data of the main urban areas clustered together in a corresponding third group (group 3), which lay between Lebowa/Dikgale on the one hand and BRISK on the other. Group 1 was regarded as the cluster of studies that consumed large portions of food (specifically maize) and included: Northern Province (urban and rural), Free State (urban and rural), North West (urban and rural) and rural areas of Mpumalanga, Eastern Cape, Gauteng and KwaZulu-Natal. Group 2, on the other hand, included studies where participants consumed smaller portion sizes yet consumed a large variety of food items. This group included the Western Cape urban and rural areas. Group 3 formed a cluster that lay between groups 1 and 2. Group 3 included all of the remaining urban areas: Gauteng, Eastern Cape, KwaZulu-Natal, Mpumalanga and Northern Cape.

Equations were developed to determine combined estimates for different population groups by two different methods.

\section{Method 1}

- Estimation of group 1. Adult consumption was estimated by taking the average values of Dikgale and Lebowa adult data. These data formed a pivotal point of group 1. Dikgale and Lebowa data complemented each other, since the latter included adolescents and the former adults.

- Estimation of group 2. CORIS data represented the white population of the Western Cape, and BRISK data 
Table 3 Comparison of age groups in terms of quantity of food (in grams) and kilojoules consumed based on dietary surveys ${ }^{\star}$

\begin{tabular}{|c|c|c|c|c|c|}
\hline Study & $\begin{array}{l}\text { Age group } \\
\text { (years) }\end{array}$ & $n$ & $\begin{array}{l}\text { Total grams } \\
\text { consumed } \\
\text { per day (SD)† }\end{array}$ & $\begin{array}{l}\text { Total kilojoules } \\
\text { consumed } \\
\text { per day } \\
\text { (SD) } \dagger\end{array}$ & $\begin{array}{l}\text { Notes on test (where appropriate) } \\
\text { for significant differences }\end{array}$ \\
\hline NFCS & $\begin{array}{l}1-5 \\
6-9\end{array}$ & $\begin{array}{r}2072 \\
832\end{array}$ & $\begin{array}{l}1083^{\mathrm{a}}(453) \\
1224^{\mathrm{b}}(480)\end{array}$ & $\begin{array}{l}4531^{\mathrm{a}}(2121) \\
5722^{\mathrm{b}}(2419)\end{array}$ & $\begin{array}{l}\text { Significant difference between the two age } \\
\text { groups for both quantity and kilojoules } \\
\text { consumed (independent } t \text {-test) }\end{array}$ \\
\hline BRISK & $\begin{array}{c}1-5 \\
6-9 \\
10-13 \\
14-18 \\
19-24 \\
25-39 \\
40-59 \\
60+\end{array}$ & $\begin{array}{l}127 \\
137 \\
133 \\
146 \\
199 \\
372 \\
245 \\
148\end{array}$ & $\begin{array}{c}1305^{\mathrm{e}}(440) \\
1422^{\mathrm{ed}}(454) \\
1662^{\mathrm{dc}}(542) \\
1825^{\mathrm{cb}}(604) \\
1889^{\mathrm{cb}}(694) \\
1987^{\mathrm{ba}}(832) \\
2220^{\mathrm{a}}(1075) \\
1915^{\mathrm{cb}}(823)\end{array}$ & $\begin{array}{r}5271^{\mathrm{c}}(1721) \\
6426^{\mathrm{b}}(2180) \\
7082^{\mathrm{ab}}(2365) \\
7993^{\mathrm{a}}(3378) \\
7748^{\mathrm{a}}(3122) \\
7541^{\mathrm{a}}(3398) \\
7250^{\mathrm{ab}}(3444) \\
6289^{\mathrm{bc}}(2933)\end{array}$ & $\begin{array}{l}\text { For both kilojoules and grams, } \\
\text { the } 10-13 \text {-year-olds consumed smaller } \\
\text { quantities than older groups, but these } \\
\text { differences were not significant (Bonferroni) }\end{array}$ \\
\hline CORIS & $\begin{array}{l}14-18 \\
19-24 \\
25-39 \\
40-59 \\
60+\end{array}$ & $\begin{array}{l}281 \\
127 \\
463 \\
686 \\
227\end{array}$ & $\begin{array}{l}2804^{\mathrm{a}}(1699) \\
2860^{\mathrm{a}}(1521) \\
2703^{\mathrm{a}}(1458) \\
2523^{\mathrm{a}}(1185) \\
2601^{\mathrm{a}}(1532)\end{array}$ & $\begin{array}{r}14225^{\mathrm{a}}(9613) \\
12993^{\mathrm{a}}(8397) \\
11091^{\mathrm{b}}(6506) \\
9946^{\mathrm{b}}(5592) \\
9749^{\mathrm{b}}(4934)\end{array}$ & $\begin{array}{l}\text { No significant difference in quantities } \\
\text { consumed, 14-24-year-olds consumed } \\
\text { significantly more kilojoules than older groups } \\
\text { (Bonferroni) }\end{array}$ \\
\hline $\begin{array}{l}\text { Lebowa } \\
\text { Study }\end{array}$ & $\begin{array}{c}1-5 \\
6-9 \\
10-13 \\
14-18 \\
19-24\end{array}$ & $\begin{array}{r}118 \\
73 \\
187 \\
75 \\
29\end{array}$ & $\begin{array}{l}1151^{\mathrm{b}}(336) \\
1632^{\mathrm{a}}(527) \\
1585^{\mathrm{a}}(498) \\
1617^{\mathrm{a}}(547) \\
1771^{\mathrm{a}}(489)\end{array}$ & $\begin{array}{l}5211^{\mathrm{b}}(1734) \\
7755^{\mathrm{a}}(2881) \\
7671^{\mathrm{a}}(2813) \\
7707^{\mathrm{a}}(2756) \\
7815^{\mathrm{a}}(2256)\end{array}$ & $\begin{array}{l}\text { Only the } 1-5 \text {-year-olds differed significantly } \\
\text { from other groups when comparing } \\
\text { average kilojoule intake and total grams } \\
\text { consumed. The other age groups had } \\
\text { similar means (Bonferroni) }\end{array}$ \\
\hline $\begin{array}{l}\text { Dikgale } \\
\text { Study }\end{array}$ & $\begin{array}{l}19-24 \\
25-39 \\
40-59 \\
60+\end{array}$ & $\begin{array}{r}2 \\
33 \\
37 \\
37\end{array}$ & $\begin{array}{l}1245(65) \\
1848(762) \\
2079(1408) \\
1896(511)\end{array}$ & $\begin{array}{l}4561(19) \\
6702(3732) \\
7270(3823) \\
7268(2456)\end{array}$ & $\begin{array}{l}\text { No significant differences between the four } \\
\text { groups for quantity and kilojoules consumed } \\
\text { (Kruskal—Wallis test) }\end{array}$ \\
\hline $\begin{array}{l}\text { THUSA } \\
\text { Bana }\end{array}$ & $\begin{array}{l}10-13 \\
14-18\end{array}$ & $\begin{array}{l}498 \\
189\end{array}$ & $\begin{array}{l}1311^{\mathrm{a}}(551) \\
1262^{\mathrm{a}}(516)\end{array}$ & $\begin{array}{r}11784^{\mathrm{a}}(7369) \\
9982^{\mathrm{b}}(5849)\end{array}$ & $\begin{array}{l}\text { 10-13-year-olds consumed more in terms of } \\
\text { quantity and kilojoules but only kilojoules } \\
\text { significant (independent } t \text {-test) }\end{array}$ \\
\hline THUSA & $\begin{array}{l}14-18 \\
19-24 \\
25-39 \\
40-59 \\
60+\end{array}$ & $\begin{array}{r}81 \\
137 \\
318 \\
302 \\
52\end{array}$ & $\begin{array}{r}1861^{\mathrm{b}}(599) \\
2007^{\mathrm{ba}}(807) \\
2123^{\text {ba }}(787) \\
2207^{\mathrm{a}}(923) \\
2092^{\text {ba }}(909)\end{array}$ & $\begin{array}{l}13588^{\mathrm{a}}(5059) \\
14251^{\mathrm{a}}(5542) \\
14025^{\mathrm{a}}(5995) \\
13569^{\mathrm{a}}(6358) \\
13270^{\mathrm{a}}(6317)\end{array}$ & Both variables in no group was $d$ \\
\hline $\begin{array}{l}\text { FYFS } \\
\text { Project }\end{array}$ & $\begin{array}{l}\leq 18 \\
19-24 \\
\geq 25\end{array}$ & $\begin{array}{l}52 \\
63 \\
21\end{array}$ & $\begin{array}{l}2521^{\mathrm{a}}(1272) \\
2043^{\mathrm{a}}(724) \\
2153^{\mathrm{a}}(709)\end{array}$ & $\begin{array}{r}11929^{\mathrm{a}}(3772) \\
9995^{\mathrm{ab}}(3381) \\
9904^{\mathrm{b}}(3056)\end{array}$ & $\begin{array}{l}\text { No difference found in quantities, but an } \\
\text { increase and then a decrease found in } \\
\text { kilojoules. The } \leq 18 \text {-year-olds differed } \\
\text { significantly from the } \geq 25 \text {-year-olds } \\
\text { (Bonferroni) }\end{array}$ \\
\hline WRFS & $\begin{array}{l}<25 \\
25-34 \\
35-44 \\
45-54 \\
55-64 \\
65+\end{array}$ & $\begin{array}{r}43 \\
124 \\
117 \\
93 \\
61 \\
9\end{array}$ & $\begin{array}{l}2270^{\mathrm{a}}(876) \\
2231^{\mathrm{a}}(761) \\
2296^{\mathrm{a}}(844) \\
2100^{\mathrm{a}}(647) \\
2108^{\mathrm{a}}(711) \\
1997^{\mathrm{a}}(749)\end{array}$ & $\begin{array}{r}8508^{\mathrm{a}}(2972) \\
7624^{\mathrm{ab}}(2611) \\
7388^{\mathrm{ab}}(2576) \\
6624^{\mathrm{b}}(2354) \\
6398^{\mathrm{b}}(2253) \\
6963^{\mathrm{ab}}(2520)\end{array}$ & $\begin{array}{l}\text { No significant differences found in quantities } \\
\text { consumed, but the younger group consumed } \\
\text { more in terms of kilojoules than the } \\
\text { middle-aged groups (Bonferroni) }\end{array}$ \\
\hline
\end{tabular}

SD - standard deviation.

${ }^{*}$ For abbreviations and sources of the studies, see Table 1.

†Differing superscript letters indicate that the means are significantly different.

represented the black population of the Western Cape. Because of the similarities between CORIS urban and rural data, the combined databases were used in further analyses. Adult dietary intakes for the Western Cape were calculated as the weighted average of CORIS and BRISK data, using the ratio of black to non-black residents in the Western Cape as described in the 1996 Census data ${ }^{40}$.

- Estimation of group 3. The average of BRISK and the combined average of Lebowa and Dikgale data were used to estimate adult consumption for this group.

Urban and rural intakes were combined to produce a single adult estimate per province, using the ratio between urban and rural per province, as calculated from the 1996 Census data. Adult intakes (average per capita portion size and percentage of adults consuming the item) in South Africa (RSA) were estimated by applying weights according to the proportions of 
Table 4 Pearson correlation coefficients between Lebowa* data (age 10+ years) and NFCS $\dagger$ data of 6-9-year-old children, by province

\begin{tabular}{|c|c|c|c|c|c|c|c|c|c|}
\hline $\begin{array}{l}\text { Portion size } \\
\text { (POR) or \% of } \\
\text { sample (PER) } \\
\text { consuming } \\
\text { item/subgroup }\end{array}$ & Item or subgroup & & & & Best eight & elations & & & \\
\hline POR Lebowa & Item $(n=319)$ & $\begin{array}{l}\mathrm{mpr} \\
0.9899\end{array}$ & $\begin{array}{l}\text { nwu } \\
0.9773\end{array}$ & $\begin{array}{l}\text { npr } \\
0.9758\end{array}$ & $\begin{array}{l}\text { fsr } \\
0.9719\end{array}$ & $\begin{array}{l}\text { fsu } \\
0.9614\end{array}$ & $\begin{array}{l}\text { nwr } \\
0.9562\end{array}$ & $\begin{array}{l}\text { kzr } \\
0.9473\end{array}$ & $\begin{array}{l}\text { gpr } \\
0.9434\end{array}$ \\
\hline PER Lebowa & Item $(n=319)$ & $\begin{array}{l}\mathrm{mpr} \\
0.9394\end{array}$ & $\begin{array}{l}\text { kzr } \\
0.8866\end{array}$ & $\begin{array}{l}\text { gpu } \\
0.8773\end{array}$ & $\begin{array}{l}\text { nwr } \\
0.8428\end{array}$ & $\begin{array}{l}\text { npu } \\
0.8412\end{array}$ & $\begin{array}{l}\text { npr } \\
0.8356\end{array}$ & $\begin{array}{l}\text { nwu } \\
0.8338\end{array}$ & $\begin{array}{l}\text { gpr } \\
0.8331\end{array}$ \\
\hline POR Lebowa & Subgroup $(n=57)$ & $\begin{array}{l}\mathrm{mpr} \\
0.9930\end{array}$ & $\begin{array}{l}\text { npr } \\
0.9865\end{array}$ & $\begin{array}{l}\text { nwu } \\
0.9816\end{array}$ & $\begin{array}{l}\text { fsr } \\
0.9812\end{array}$ & $\begin{array}{l}\text { ecr } \\
0.9737\end{array}$ & $\begin{array}{l}\text { fsu } \\
0.9720\end{array}$ & $\begin{array}{l}\text { gpr } \\
0.9610\end{array}$ & $\begin{array}{l}\text { nwr } \\
0.9608\end{array}$ \\
\hline PER Lebowa & Subgroup $(n=57)$ & $\begin{array}{l}\mathrm{mpr} \\
0.9786\end{array}$ & $\begin{array}{l}\text { gpr } \\
0.9610\end{array}$ & $\begin{array}{l}\text { npu } \\
0.9414\end{array}$ & $\begin{array}{l}\text { gpu } \\
0.9264\end{array}$ & $\begin{array}{l}\text { kzr } \\
0.9251\end{array}$ & $\begin{array}{l}\text { ecr } \\
0.9209\end{array}$ & $\begin{array}{l}\text { npr } \\
0.9153\end{array}$ & $\begin{array}{l}\text { fsu } \\
0.9038\end{array}$ \\
\hline
\end{tabular}

* Lebowa Study (Steyn et al., 19927).

† National Food Consumption Survey (Labadarios et al., 20006).

‡First two symbols indicate the NFCS province: $\mathrm{ec}=$ Eastern Cape, fs $=$ Free State, gp $=$ Gauteng, $\mathrm{kz}=\mathrm{KwaZulu}-\mathrm{Natal}, \mathrm{mp}=\mathrm{Mpumalanga}$, $\mathrm{np}=$ Northern Province, $\mathrm{nw}=$ North West Province and $\mathrm{wc}=$ Western Cape Province; third symbol: $r=$ rural and $u=u r b a n$.

populations in each province ${ }^{40}$ as follows:

$$
\begin{aligned}
\mathrm{RSA}= & 0.155 \times \mathrm{EC}+0.065 \times \mathrm{FS}+0.181 \times \mathrm{GP}+0.207 \\
& \times \mathrm{KZ}+0.069 \times \mathrm{MP}+0.021 \times \mathrm{NC}+0.122 \times \mathrm{NP} \\
& +0.083 \times \mathrm{NW}+0.097 \times \mathrm{WC},
\end{aligned}
$$

RSA $($ rural $)=0.21 \times \mathrm{EC}+0.05 \times \mathrm{FS}+0.01 \times \mathrm{GP}+0.26$

$$
\begin{aligned}
& \times \mathrm{KZ}+0.09 \times \mathrm{MP}+0.01 \times \mathrm{NC}+0.23 \times \mathrm{NP} \\
& +0.12 \times \mathrm{NW}+0.02 \times \mathrm{WC}
\end{aligned}
$$

and

$$
\begin{aligned}
\mathrm{RSA}(\text { urban })= & 0.11 \times \mathrm{EC}+0.08 \times \mathrm{FS}+0.33 \times \mathrm{GP}+0.17 \\
& \times \mathrm{KZ}+0.05 \times \mathrm{MP}+0.03 \times \mathrm{NC}+0.02 \\
& \times \mathrm{NP}+0.05 \times \mathrm{NW}+0.16 \times \mathrm{WC},
\end{aligned}
$$

where $\mathrm{EC}=$ Eastern Cape, $\mathrm{FS}=$ Free State, $\mathrm{GP}=$ Gauteng, $\mathrm{KZ}=$ KwaZulu-Natal, $\mathrm{MP}=$ Mpumalanga, $\mathrm{NP}=$ Northern Province, $\mathrm{NW}=$ North West Province and $\mathrm{WC}=$ Western Cape Province.

These equations were further simplified and adjusted for sample size, in terms of the original databases, to:

$$
\begin{aligned}
\text { RSA }= & 4.365 \times \text { Lebowa }+5.901 \times \text { Dikgale }+0.575 \\
& \times \text { BRISK }+0.152 \times \text { CORIS },
\end{aligned}
$$

$$
\begin{aligned}
\text { RSA }(\text { rural })= & 5.932 \times \text { Lebowa }+8.019 \times \text { Dikgale }+0.011 \\
& \times \text { BRISK }+0.032 \times \text { CORIS }
\end{aligned}
$$

and

$$
\begin{aligned}
\text { RSA }(\text { urban })= & 3.002 \times \text { Lebowa }+4.059 \times \text { Dikgale } \\
& +1.078 \times \text { BRISK }+0.250 \times \text { CORIS } .
\end{aligned}
$$

\section{Method 2}

Adult data were calculated by using proportions of urban and rural data for black and non-black ethnic groups according to the 1996 Census results ${ }^{40}$. BRISK represented urban blacks, the average of Lebowa and Dikgale represented rural blacks, CORIS-urban represented non-black urban and CORIS-rural represented non-black rural. In terms of the original databases, after adjusting for sample size, the following equations were obtained:

$$
\begin{aligned}
& \text { RSA }=0.642 \times \text { CORIS }- \text { urban }+0.152 \times \text { CORIS }- \text { rural } \\
& +0.948 \times \text { BRISK }+2.628 \times \text { Lebowa }+3.553 \\
& \times \text { Dikgale, } \\
& \text { RSA }(\text { rural })=0.110 \times \text { CORIS }- \text { rural }+1.874 \times \text { Lebowa } \\
& +2.534 \times \text { Dikgale }
\end{aligned}
$$

\section{Results and discussion}

Table 6 provides a comprehensive table of the GEMS/ Food main food groups for all South Africans. The percentages of the age groups consuming the GEMS/Food groups were similar throughout. The main three GEMS/ Food groups were the same for all age groups, being cereals, sugars and honey, and stimulants. Cereals were consumed by $99 \%$ of all age groups and sugar and honey by more than $80 \%$. The average consumption of cooked cereals was $493 \mathrm{~g}$ in 1-5-year-olds, $559 \mathrm{~g}$ in 6-9-year-olds and $690-879 \mathrm{~g}$ in 10+-year-olds when taking the group of consumers into consideration. Infant foods, animal oils, spices, alcoholic beverages, supplements and condiments were consumed by less than $3 \%$ of $1-9$-year-olds. In the $10+$-year-old group, less than $3 \%$ consumed soups, condiments, supplements, human and formula milk, and spices. The meat and offal group was consumed by $48 \%$ of 
Table 5 Calculation of adjusted relative weightings used to calculate intakes of South African adults

\begin{tabular}{|c|c|c|c|c|c|c|}
\hline \multirow[b]{3}{*}{ Group } & \multirow[b]{3}{*}{ Step } & \multicolumn{5}{|c|}{ Dataset $†$} \\
\hline & & \multirow[b]{2}{*}{ Dikgale } & \multirow[b]{2}{*}{ Lebowa } & \multirow[b]{2}{*}{ BRISK } & \multicolumn{2}{|c|}{ CORIS } \\
\hline & & & & & Urban & Rural \\
\hline \multicolumn{7}{|l|}{ Method $1^{*}$} \\
\hline \multirow[t]{3}{*}{$\operatorname{RSA}(n=3535)$} & $A=$ weighting of dataset $^{\star}$ & 0.3606 & 0.3606 & 0.2022 & 0.0766 & - \\
\hline & $B=$ sample size & 216 & 292 & 1243 & 1784 & - \\
\hline & Adjusted relative weighting $=(A \times 3535) / B$ & 5.901 & 4.365 & 0.575 & 0.152 & - \\
\hline \multirow[t]{3}{*}{ RSA urban $(n=3535)$} & $A=$ weighting of dataset $^{\star}$ & 0.248 & 0.248 & 0.379 & 0.126 & - \\
\hline & $B=$ sample size & 216 & 292 & 1243 & 1784 & - \\
\hline & Adjusted relative weighting $=(A \times 3535) / B$ & 4.059 & 3.002 & 1.078 & 0.250 & - \\
\hline \multirow[t]{3}{*}{ RSA rural $(n=3535)$} & $A=$ weighting of dataset $^{*}$ & 0.490 & 0.490 & 0.004 & 0.016 & - \\
\hline & $B=$ sample size & 216 & 292 & 1243 & 1784 & - \\
\hline & Adjusted relative weighting $=(A \times 3535) / B$ & 8.019 & 5.932 & 0.011 & 0.032 & - \\
\hline \multicolumn{7}{|l|}{ Method $2^{\star}$} \\
\hline \multirow[t]{3}{*}{$\mathrm{RSA}(n=3535)$} & $A=$ weighting of dataset ${ }^{\star}$ & 0.2171 & 0.2171 & 0.3332 & 0.204 & 0.028 \\
\hline & $B=$ sample size & 216 & 292 & 1243 & 1125 & 659 \\
\hline & Adjusted relative weighting $=(A \times 3535) / B$ & 3.553 & 2.628 & 0.948 & 0.642 & 0.152 \\
\hline \multirow[t]{3}{*}{ RSA urban $(n=2368)$} & $A=$ weighting of dataset ${ }^{*}$ & - & - & 0.620 & 0.380 & - \\
\hline & $B=$ sample size & - & - & 1243 & 1125 & - \\
\hline & Adjusted relative weighting $=(A \times 2368) / B$ & - & - & 1.181 & 0.800 & - \\
\hline \multirow[t]{3}{*}{ RSA rural $(n=1167)$} & $A=$ weighting of dataset $^{*}$ & 0.469 & 0.469 & - & - & 0.062 \\
\hline & $B=$ sample size & 216 & 292 & - & - & 659 \\
\hline & Adjusted relative weighting $=(A \times 1167) / B$ & 2.534 & 1.874 & - & - & 0.110 \\
\hline
\end{tabular}

RSA - Republic of South Africa.

* See text for description.

†For abbreviations and sources of the studies, see Table 1.

Table 6 Comprehensive table of GEMS/Food main food groups consumed by children* and adults $†$ in South Africa

\begin{tabular}{|c|c|c|c|c|c|}
\hline Age group & GEMS/Food main group & $\begin{array}{l}\% \text { of sample } \\
\text { consuming } \\
\text { the item }\end{array}$ & $\begin{array}{c}\text { Average } \\
\text { consumption } \\
\left(\text { g day }^{-1}\right)\end{array}$ & $\begin{array}{l}\text { SD of average } \\
\text { consumption }\end{array}$ & $\begin{array}{c}\text { Average per } \\
\text { capita consumption } \\
\left(\mathrm{g} \mathrm{day}^{-1}\right)\end{array}$ \\
\hline $\begin{array}{l}\text { Children aged } 1-5 \text { years } \\
(n=2048)\end{array}$ & $\begin{array}{l}\text { CEREALS } \\
\text { SUGARS } \\
\text { STIMULANTS } \\
\text { MILK } \\
\text { MEAT + OFFAL } \\
\text { VEGETABLES } \\
\text { VEG_OILS } \\
\text { ROOTS } \\
\text { FRUIT } \\
\text { EGGS } \\
\text { PULSES } \\
\text { NUTS + OILSEEDS } \\
\text { FISH } \\
\text { HUMAN MILK } \\
\text { SOUPS } \\
\text { ALCOHOL } \\
\text { INFANT FOODS } \\
\text { CONDIMENTS } \\
\text { ANIMAL FAT } \\
\text { SPICES } \\
\text { SUPPLEMENTS }\end{array}$ & $\begin{array}{l}99.22 \\
82.64 \\
63.82 \\
56.27 \\
47.93 \\
43.64 \\
36.76 \\
26.38 \\
21.60 \\
13.21 \\
10.73 \\
7.70 \\
7.56 \\
6.92 \\
3.95 \\
2.58 \\
1.85 \\
1.41 \\
0.73 \\
0.20 \\
0.20\end{array}$ & $\begin{array}{r}493.00 \\
79.23 \\
230.21 \\
220.21 \\
94.08 \\
118.07 \\
12.70 \\
110.64 \\
222.58 \\
71.92 \\
154.07 \\
14.66 \\
89.66 \\
366.96 \\
147.12 \\
420.75 \\
105.29 \\
11.62 \\
15.67 \\
1.25 \\
75.25\end{array}$ & $\begin{array}{r}301.11 \\
141.77 \\
123.48 \\
223.65 \\
69.64 \\
96.86 \\
11.21 \\
81.82 \\
167.61 \\
32.04 \\
109.35 \\
17.39 \\
90.41 \\
324.86 \\
95.94 \\
240.51 \\
115.44 \\
20.66 \\
9.52 \\
0.5 \\
54.30\end{array}$ & $\begin{array}{c}489.15 \\
65.48 \\
146.93 \\
123.9 \\
45.09 \\
51.52 \\
4.67 \\
29.18 \\
48.07 \\
9.50 \\
16.53 \\
1.13 \\
6.78 \\
25.41 \\
5.81 \\
10.87 \\
1.95 \\
0.16 \\
0.11 \\
0.00 \\
0.14\end{array}$ \\
\hline $\begin{array}{l}\text { Children aged } 6-9 \text { years } \\
(n=817)\end{array}$ & $\begin{array}{l}\text { CEREALS } \\
\text { SUGARS } \\
\text { STIMULANTS } \\
\text { MEAT + OFFAL } \\
\text { MILK } \\
\text { VEG_OILS } \\
\text { VEGETABLES } \\
\text { ROOTS } \\
\text { FRUIT } \\
\text { PULSES } \\
\text { EGGS }\end{array}$ & $\begin{array}{l}99.88 \\
85.07 \\
69.89 \\
52.02 \\
48.84 \\
45.29 \\
44.55 \\
25.46 \\
20.93 \\
12.73 \\
12.48\end{array}$ & $\begin{array}{r}559.28 \\
120.19 \\
254.94 \\
122.29 \\
207.39 \\
17.78 \\
130.93 \\
137.86 \\
286.81 \\
186.07 \\
79.99\end{array}$ & $\begin{array}{r}324.53 \\
188.17 \\
125.91 \\
92.14 \\
197.39 \\
20.87 \\
98.12 \\
120.07 \\
229.20 \\
124.01 \\
37.88\end{array}$ & $\begin{array}{r}558.59 \\
102.24 \\
178.18 \\
63.61 \\
101.28 \\
8.05 \\
58.34 \\
35.10 \\
60.03 \\
23.69 \\
9.99\end{array}$ \\
\hline
\end{tabular}


Table 6. Continued

\begin{tabular}{|c|c|c|c|c|c|}
\hline Age group & GEMS/Food main group & $\begin{array}{l}\% \text { of sample } \\
\text { consuming } \\
\text { the item }\end{array}$ & $\begin{array}{c}\text { Average } \\
\text { consumption } \\
\left(\text { g day }^{-1}\right)\end{array}$ & $\begin{array}{l}\text { SD of average } \\
\text { consumption }\end{array}$ & $\begin{array}{c}\text { Average per } \\
\text { capita consumption } \\
\left(\mathrm{g} \mathrm{day}^{-1}\right)\end{array}$ \\
\hline & NUTS + OILSEEDS & 11.51 & 17.04 & 14.24 & 1.96 \\
\hline & $\mathrm{FISH}$ & 8.69 & 84.23 & 54.16 & 7.32 \\
\hline & SOUPS & 5.02 & 152.37 & 94.38 & 7.65 \\
\hline & ALCOHOL & 1.84 & 343.67 & 178.07 & 6.31 \\
\hline & CONDIMENTS & 1.35 & 34.27 & 58.92 & 0.46 \\
\hline & ANIMAL FAT & 1.10 & 23.33 & 26.16 & 0.26 \\
\hline & SPICES & 0.98 & 2.19 & 1.81 & 0.02 \\
\hline & SUPPLEMENTS & 0.61 & 30.40 & 5.37 & 0.19 \\
\hline & INFANT FOODS & 0.37 & 23.33 & 23.86 & 0.09 \\
\hline \multirow[t]{21}{*}{ Adults aged $10+$ years, Method 1} & CEREALS & 98.95 & 878.74 & 579.11 & 869.48 \\
\hline & SUGARS & 80.47 & 94.98 & 187.43 & 76.44 \\
\hline & STIMULANTS & 78.35 & 487.71 & 446.59 & 382.10 \\
\hline & MEAT + OFFAL & 57.39 & 149.38 & 119.52 & 85.72 \\
\hline & VEGETABLES & 55.75 & 165.99 & 153.09 & 92.53 \\
\hline & VEG_OILS & 47.91 & 16.46 & 14.48 & 7.88 \\
\hline & MILK & 30.64 & 239.13 & 179.96 & 73.27 \\
\hline & FRUIT & 21.39 & 286.72 & 186.73 & 61.32 \\
\hline & ROOTS & 21.03 & 191.31 & 93.25 & 40.24 \\
\hline & EGGS & 15.04 & 100.86 & 41.64 & 15.17 \\
\hline & PULSES & 14.00 & 248.77 & 363.74 & 34.82 \\
\hline & $\mathrm{FISH}$ & 10.51 & 113.46 & 61.52 & 11.93 \\
\hline & NUTS + OILSEEDS & 6.66 & 27.91 & 27.50 & 1.86 \\
\hline & ANIMAL FAT & 6.60 & 15.57 & 21.70 & 1.03 \\
\hline & ALCOHOL & 5.99 & 898.11 & 756.35 & 53.80 \\
\hline & SOUPS & 1.72 & 148.50 & 130.21 & 2.56 \\
\hline & CONDIMENTS & 1.53 & 31.38 & 18.73 & 0.48 \\
\hline & SUPPLEMENTS & 0.18 & 28.48 & 38.65 & 0.05 \\
\hline & HUMAN MILK & 0.12 & 6.00 & 0.00 & 0.01 \\
\hline & INFANT FOODS & 0.01 & 69.00 & 7.72 & 0.01 \\
\hline & SPICES & 0.01 & 3.50 & 0.83 & 0.00 \\
\hline \multirow[t]{21}{*}{ Adults aged $10+$ years, Method 2} & CEREALS & 98.62 & 689.93 & 545.02 & 680.44 \\
\hline & SUGARS & 83.62 & 156.56 & 257.99 & 130.91 \\
\hline & STIMULANTS & 80.42 & 547.93 & 509.36 & 440.63 \\
\hline & MEAT + OFFAL & 67.32 & 169.61 & 146.44 & 114.17 \\
\hline & VEG_OILS & 58.22 & 21.35 & 20.79 & 12.43 \\
\hline & VEGETABLES & 56.96 & 159.77 & 150.29 & 91.01 \\
\hline & MILK & 48.18 & 267.84 & 232.70 & 129.05 \\
\hline & ROOTS & 36.43 & 191.08 & 118.19 & 69.62 \\
\hline & FRUIT & 31.64 & 325.22 & 267.80 & 102.91 \\
\hline & EGGS & 17.79 & 93.66 & 45.45 & 16.66 \\
\hline & PULSES & 15.23 & 234.05 & 305.27 & 35.66 \\
\hline & $\mathrm{FISH}$ & 12.23 & 125.44 & 84.84 & 15.35 \\
\hline & ANIMAL FAT & 10.84 & 12.87 & 19.13 & 1.39 \\
\hline & ALCOHOL & 9.71 & 709.04 & 812.38 & 68.83 \\
\hline & NUTS + OILSEEDS & 6.22 & 31.01 & 35.13 & 1.93 \\
\hline & CONDIMENTS & 3.91 & 19.77 & 23.52 & 0.77 \\
\hline & SOUPS & 2.28 & 204.13 & 154.95 & 4.66 \\
\hline & SUPPLEMENTS & 0.25 & 53.23 & 69.52 & 0.13 \\
\hline & HUMAN MILK & 0.07 & 6.00 & 0.00 & 0.00 \\
\hline & INFANT FOODS & 0.04 & 69.00 & 15.86 & 0.03 \\
\hline & SPICES & 0.02 & 2.57 & 1.05 & 0.00 \\
\hline
\end{tabular}

GEMS/Food - Global Environment Monitoring System/Food Contamination Monitoring and Assessment Programme; SD - standard deviation. ${ }^{*}$ Adapted from the National Food Consumption Survey, 24-hour recall (Labadarios et al., $2000^{6}$ ).

† Methods 1 and 2, as described in the text.

1-9-year-olds and by 57-67\% of the older group. An egg product was consumed by $13-18 \%$ of participants and $11-15 \%$ consumed pulses.

A comparison of the data extrapolated in this study with FBSs for South Africa is presented in Table 7. This step was undertaken in order to assess the relative validity of the data generated. However, it should be kept in mind that comparisons can only be made in terms of energy intake since the FBSs give raw food values whereas the data generated were for cooked foods. Generally FBS values compared favourably with the data generated for adults. FBS values were higher with respect to the consumption of milk, pork, fats and oils, maize, rice and sugar. Beef and offal, eggs, oats, potatoes and fruit consumption values were similar to FBS data. FBS items that showed lower consumption in comparison with data generated were 
Table 7 Comparison of mean consumption data for children* and adults† with data from food balance sheets (FBSs) for South Africa

\begin{tabular}{|c|c|c|c|c|c|c|c|c|c|c|}
\hline & \multicolumn{4}{|c|}{ Quantity $\left(\right.$ g day $^{-1}$ ) } & \multirow[b]{3}{*}{$\begin{array}{c}\text { FBS } \\
\left(\text { g day }^{-1}\right)\end{array}$} & \multicolumn{4}{|c|}{ Energy intake $\left(\mathrm{kJ}\right.$ day $\left.^{-1}\right)$} & \multirow[b]{3}{*}{$\begin{array}{c}\text { FBS } \\
\left(\mathrm{kJ} \mathrm{day}^{-1}\right)\end{array}$} \\
\hline & \multirow[b]{2}{*}{$\begin{array}{c}1-5 \\
\text { years }\end{array}$} & \multirow[b]{2}{*}{$\begin{array}{c}6-9 \\
\text { years }\end{array}$} & \multicolumn{2}{|c|}{$10+$ years } & & \multirow[b]{2}{*}{$\begin{array}{c}1-5 \\
\text { years }\end{array}$} & \multirow[b]{2}{*}{$\begin{array}{c}6-9 \\
\text { years }\end{array}$} & \multicolumn{2}{|c|}{$10+$ years } & \\
\hline & & & Method 1 & Method 2 & & & & Method 1 & Method 2 & \\
\hline $\begin{array}{l}\text { Milk \& butter } \\
\text { Meat }\end{array}$ & 123.9 & 101.2 & 73.5 & 129.2 & 134.4 & 358.7 & 300.9 & 235.9 & 412.1 & 413.8 \\
\hline Beef \& offal & 20.4 & 27.6 & 37.9 & 50.00 & 37.3 & 180.6 & 243.9 & 394.7 & 536.6 & 430.1 \\
\hline Venison & 0 & 0 & 0.3 & 0.6 & - & 0 & 0 & 1.6 & 3.7 & - \\
\hline Mutton/goat \& offal & 4.8 & 6.6 & 10.5 & 24.6 & 10.7 & 44.4 & 63.8 & 121.9 & 236 & 108.2 \\
\hline Pork \& offal & 1.6 & 2.4 & 2.6 & 5.2 & 8.3 & 22.3 & 28.1 & 39.6 & 69.2 & 129.9 \\
\hline Chicken \& offal & 17.9 & 26.3 & 34.6 & 33.93 & 69.4 & 137.8 & 199.5 & 300.4 & 259.4 & 375 \\
\hline Eggs & 9.5 & 10 & 15.2 & 16.7 & 19.9 & 70.1 & 75.1 & 113.5 & 128.6 & 131.6 \\
\hline Fish \& seafood & 6.8 & 7.3 & 12 & 15.4 & - & 43.2 & 47.4 & 88.6 & 109.7 & \\
\hline Insects & 0.4 & 0.8 & - & - & - & 6.2 & 13.5 & - & - & - \\
\hline Legumes & 16.5 & 23.7 & 34.9 & 35.7 & $8 \ddagger$ & 87.6 & 126.8 & 203 & 185.4 & 114.6 \\
\hline Nuts (mainly peanuts) & 1.1 & 2 & 1.9 & 1.9 & 3.2 & 27.6 & 48.4 & 48.5 & 60.9 & 76.9 \\
\hline Vegetable oils & 4.7 & 8.1 & 7.9 & 12.4 & - & 130.1 & 215.9 & 222.7 & 431.1 & - \\
\hline Animal fat & 0.1 & 0.3 & 1 & 1.4 & - & 4.2 & 9.5 & 38.1 & 48 & - \\
\hline Total fat/oils & 4.8 & 8.4 & 8.0 & 13.8 & 26.3 & 134.3 & 225.4 & 260.8 & 479.1 & 926.6 \\
\hline \multicolumn{11}{|l|}{ Cereals } \\
\hline Maize & 364.3 & 392.9 & 690.1 & 475.1 & $235 \ddagger$ & 1490 & 1733 & 2859 & 1931 & 3267 \\
\hline Wheat & 64.5 & 109.2 & 153 & 160.6 & $140 \ddagger$ & 708.9 & 1233 & 1721 & 2058 & 2001 \\
\hline Sorghum & 16.2 & 7.2 & 1.7 & 1.4 & 4.2 & 64.1 & 29.3 & 3 & 2 & 62.4 \\
\hline Barley & 0 & 0 & 0 & 0 & 14.3 & 0 & 0 & 0 & 0 & 209.5 \\
\hline Oats & 7.7 & 5 & 2.8 & 5.8 & $0.5 \ddagger$ & 21.7 & 17.4 & 9.3 & 22 & 10.8 \\
\hline Rice & 36.6 & 44.2 & 22.2 & 37 & $34.2 \ddagger$ & 195.4 & 240.3 & 118.5 & 204.4 & 515.8 \\
\hline Rye & 0 & 0 & 0 & 0.1 & - & 0 & 0 & 0.3 & 0.8 & - \\
\hline Roots/tubers (e.g. potatoes) & 29.2 & 35.1 & 40.4 & 69.7 & 87 & 158.5 & 223.8 & 189.8 & 363.6 & 254.6 \\
\hline \multicolumn{11}{|l|}{ Vegetables } \\
\hline Stem & 0 & 0 & 0 & 0.1 & - & 0 & 0 & 0.1 & 0.3 & - \\
\hline Brassica & 11.5 & 13.2 & 16.4 & 15 & - & 52.3 & 64.7 & 83.7 & 61.9 & - \\
\hline Leaf & 17.9 & 17.3 & 34.7 & 22.6 & - & 23.1 & 23.5 & 52.4 & 32.6 & - \\
\hline Fruiting & 10.5 & 15 & 25.4 & 28 & - & 28.8 & 44.4 & 44.5 & 59 & - \\
\hline Cucrubits & 8.8 & 9.9 & 10.9 & 14 & - & 20.4 & 25.1 & 29.6 & 37 & - \\
\hline Bulb & 0.4 & 0.4 & 0.6 & 1.3 & - & 2.6 & 2.5 & 1.9 & 3.9 & - \\
\hline Green legumes & 1.6 & 1.8 & 3 & 8 & - & 4.4 & 6 & 9.1 & 24 & - \\
\hline Mixed vegetables & 0.9 & 0.6 & 1.6 & 2 & - & 2.9 & 2 & 6.8 & 6.6 & - \\
\hline Total vegetables & 51.6 & 58.2 & 92.6 & $9 \overline{1}$ & 110.7 & 134.5 & 168.2 & 228.1 & 225.3 & 107.6 \\
\hline \multicolumn{11}{|l|}{ Fruit } \\
\hline Pome & 19.3 & 21.7 & 20.9 & 43 & - & 54.8 & 61 & 60.4 & 142.3 & - \\
\hline Tropical & 8.9 & 8.8 & 15.3 & 14.6 & - & 31.5 & 30.4 & 66.4 & 67.8 & - \\
\hline Citrus & 12.1 & 18.8 & 11.7 & 15.2 & - & 27 & 41.6 & 26 & 36.5 & - \\
\hline Stone & 4.8 & 5.7 & 6.7 & 13.1 & - & 11.4 & 13.2 & 16.9 & 39 & - \\
\hline Berry & 2.9 & 4.9 & 6.7 & 16.4 & - & 8.7 & 14.8 & 20.6 & 50.4 & - \\
\hline Other & 0.1 & 0.2 & 0.3 & 0.6 & - & 0.5 & 0.7 & 0.9 & 1.5 & - \\
\hline Total fruit & 48.1 & 60.1 & 61.6 & 102.9 & 110.4 & 133.9 & 161.7 & 191.2 & 337.5 & 257.1 \\
\hline Other items & & & & & & & & & & \\
\hline Sugar & 16.2 & 18.2 & 20.5 & 24.3 & 79.3 & 275.4 & 308.4 & 347.7 & 383.6 & 1286 \\
\hline Sugar - other & 49.2 & 84 & 56 & 106.3 & - & 97.3 & 177.5 & 129.1 & 260.8 & - \\
\hline Honey & 0 & 0 & 0.1 & 0.4 & - & 0.2 & 0.3 & 2 & 5.4 & - \\
\hline Tea & 129.9 & 154.5 & 311.1 & 275 & - & 5.9 & 7.3 & 15.6 & 13.1 & - \\
\hline Coffee & 16.5 & 22.9 & 71.4 & 164.7 & - & 1.5 & 2.1 & 6.4 & 12.8 & - \\
\hline Cocoa & 0.4 & 0.7 & 0.4 & 1.2 & 0.6 & 9.5 & 15.7 & 7.9 & 26.1 & 8.7 \\
\hline Soups & 5.8 & 7.6 & 2.6 & 4.7 & - & 9.8 & 12.6 & 4.4 & 6.3 & - \\
\hline Alcoholic beverages & 10.9 & 6.3 & 53.9 & 68.8 & - & 17.1 & 10 & 33.2 & 18.8 & - \\
\hline Infant food & 2 & 0.1 & 0 & 0 & - & 12.2 & 1.3 & 0.1 & 0.4 & - \\
\hline Condiments & 0.2 & 0.5 & 0.5 & 0.8 & - & 1.3 & 4.6 & 2.7 & 3.6 & - \\
\hline Spices & 0 & 0 & 0 & 0 & - & 0 & 0.4 & 0 & 0 & - \\
\hline Supplements & 0.1 & 0.2 & 0.1 & 0.1 & - & 1.9 & 3.4 & 0.8 & 1.8 & - \\
\hline Breast milk \& substitutes & 25.4 & 0 & 0 & 0 & - & 77.5 & 0 & 0.2 & 0.1 & - \\
\hline $\begin{array}{l}\text { Total } \\
\text { RDA§ }\end{array}$ & 1082 & 1223 & 1813 & 1917 & 1134 & $\begin{array}{l}4530 \\
5460\end{array}$ & $\begin{array}{l}5723 \\
7560\end{array}$ & $\begin{array}{l}7680 \\
7980\end{array}$ & $\begin{array}{l}8358 \\
7980\end{array}$ & 10687 \\
\hline
\end{tabular}

${ }^{*}$ Adapted from the National Food Consumption Survey, 24-hour recall (Labadarios et al., 20006).

† Methods 1 and 2 , as described in the text.

$\ddagger$ Weights are for dry products.

$\S$ Recommended Dietary Allowances (lowest of the range) (Food and Nutrition Board ${ }^{41}$ ). 


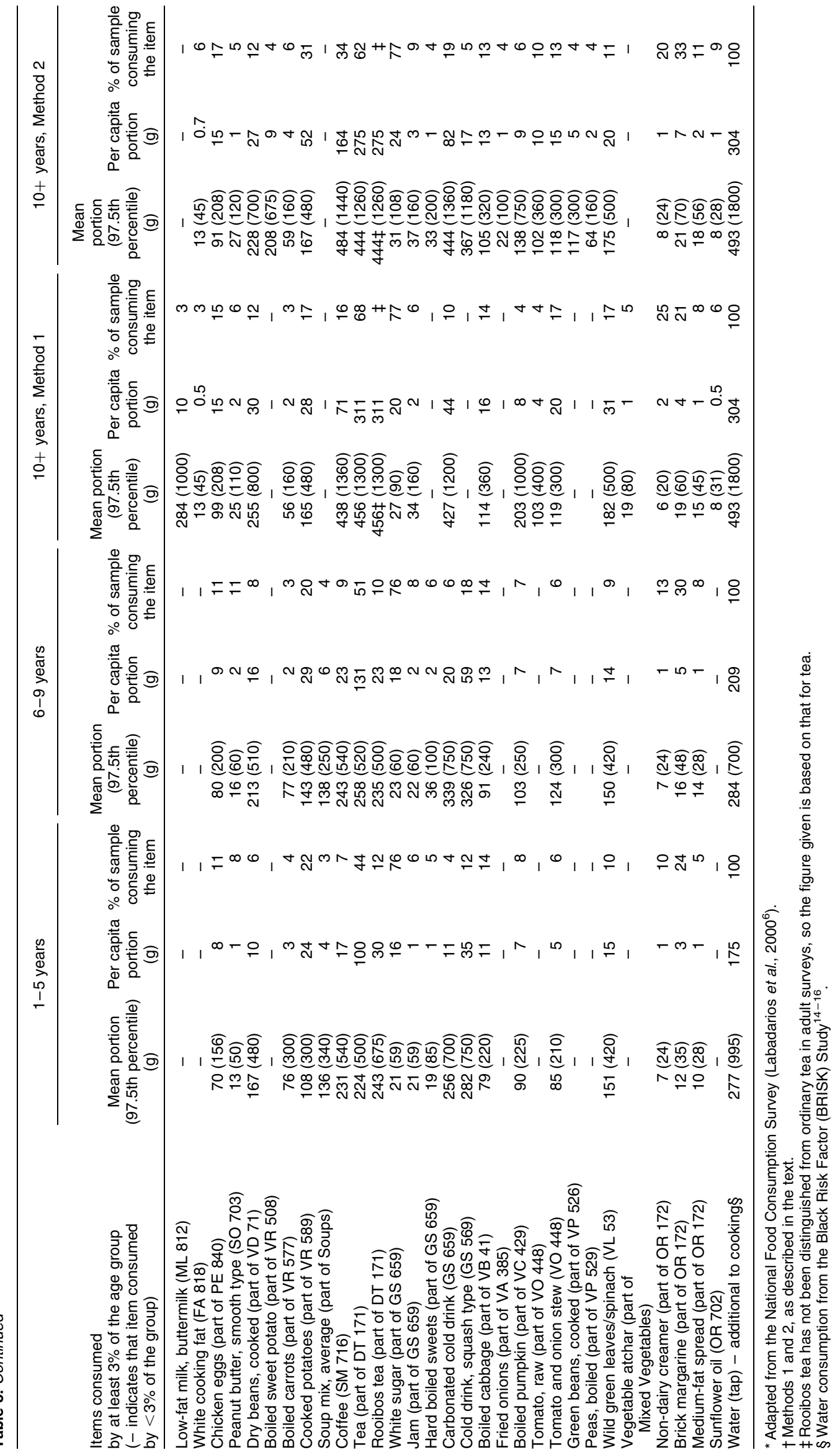


mutton and goat, legumes and vegetables. The higher consumption of these specific food items in comparison with the FBSs is probably due to the fact that sheep, goats, vegetables and legumes are frequently kept for home consumption, particularly in rural areas. Consequently these home-produced food items would not be accounted for in the FBSs.

Another measure of validity of the adult data generated was shown by a comparison of the average energy intakes of groups with the Recommended Dietary Allowances (RDAs). Such comparisons showed that adult estimates were similar to the lower range of the RDA for energy ${ }^{35}$. By comparison, the FBSs overestimated energy for adults by 28\% (Method 1) and 22\% (Method 2). This is a general finding that has been reported elsewhere ${ }^{1-4}$.

Table 8 gives commonly consumed food items for each of the age groups studied. This table comprises food items eaten by at least 3\% of the target population. Food items consumed most commonly by the South African adult population (Method 1) in descending frequency of usage and average (mean) amount per day were: maize porridge (78\%/848g), white sugar $(77 \% / 27 \mathrm{~g})$, tea $(68 \% / 456 \mathrm{~g})$, brown bread (55\%/165 g), white bread (28\%/163 g), nondairy creamer $(25 \% / 6 \mathrm{~g})$, brick margarine $(21 \% / 19 \mathrm{~g})$, chicken meat $(19 \% / 111 \mathrm{~g})$, full-cream milk (19\%/204 g) and green leaves $(17 \% / 182 \mathrm{~g})$.

It is recommended that average/mean portion size, and not per capita portion size, be used for analyses of contaminants since per capita portion size would greatly underestimate contaminants determined. Additionally it is recommended that, for adults, average portions from Method 1 be used for analyses since these give a larger estimate and a better representation of those who have a poorer socio-economic status. Items that appear in tables by means of Method 2, and not by Method 1, should be included to ensure that items eaten by the white (minority) population have not been excluded.

\section{Conclusion}

Secondary data analyses of past dietary surveys can be used to generate 'relatively' valid food consumption data for populations where nationally representative surveys are not feasible or possible. These data can be used as an alternative to food balance sheets when undertaking analyses of contaminants in foods and beverages.

\section{Acknowledgements}

This study was funded by the World Health Organization and supported by the Department of Health (Directorate: Food Control) and the Chronic Diseases of Lifestyle Unit of the Medical Research Council. We extend our gratitude to the original authors of the research databases used, particularly: Professor D Labadarios and directors of the NFCS; Dr Lesley Bourne; Dr Petro Wolmarans;
Dr U MacIntyre and Dr M Senekal. We thank Nicolene Davids and Jean Fourie for technical support.

\section{References}

1 World Health Organization (WHO). Guidelines for the Study of Dietary Intakes of Chemical Contaminants. WHO Offset Publication No. 87. Geneva: WHO, 1985.

2 World Health Organization (WHO). Guidelines for Predicting Dietary Intake of Pesticide Residues (Revised). Prepared by the Global Environment Monitoring System/Food Contamination Monitoring and Assessment Programme (GEMS/Food) in collaboration with Codex Committee on Pesticide Residues. WHO Programme of Food Safety and Food Aid. WHO/FSF/FOS/97.7. Geneva: WHO, 1997.

3 World Health Organization (WHO). GEMS/Food Regional Diets. Regional Per Capita Consumption of Raw and Semiprocessed Agricultural Commodities. Prepared by the Global Environment Monitoring System/Food Contamination Monitoring and Assessment Programme (GEMS/Food). Food Safety Unit, WHO Programme of Food Safety and Food Aid. WHO/FSF/FOS/98.3. Geneva: WHO, 1998.

4 World Health Organization (WHO). Food Consumption and Exposure Assessment of Chemicals. Report of a Food and Agriculture Organization/WHO Consultation held at Geneva, Switzerland on 10-14 February 1997. WHO/FSF/ FOS/97.5. Geneva: WHO, 1997.

5 World Health Organization (WHO). GEMS/Food Total Diet Studies. Report of a Joint US Food and Drug Administration/WHO International Workshop on Total Diet Studies in co-operation with the Pan American Health Organization held at Kansas City, MO, USA on 26 July-6 August 1999. WHO/SDE/PHE/FOS/99.9. Geneva: WHO, 1999.

6 Labadarios D, Steyn NP, Maunder E, MacIntyre U. Swart R, Gerike G, et al. The National Food Consumption Survey (NFCS): Children aged 1-9 years, South Africa, 1999. Stellenbosch: The National Food Consumption Survey (NFCS), 2000.

7 Steyn NP, Badenhorst CJ, Nel JH, Jooste PL. The nutritional status of Pedi preschool children in two rural areas of Lebowa. South African Journal of Food Science and Nutrition 1992; 4(2): 24-8.

8 Steyn NP, Badenhorst CJ, Nel JH. The meal pattern and snacking habits of schoolchildren in two rural areas of Lebowa. South African Journal of Food Science and Nutrition 1993; 5(4): 5-9.

9 Steyn NP, Badenhorst CJ, Nel JH, Ladzani R. Breast-feeding and weaning practices of Pedi mothers and the dietary intakes of their preschool children. South African Journal of Food Science and Nutrition 1993; 5(4): 10-13.

10 Badenhorst CJ, Steyn NP, Jooste PL, et al. Nutritional status of Pedi schoolchildren aged 6-14 years in two rural areas of Lebowa: a comprehensive nutritional survey of dietary intake, anthropometric, biochemical, haematological and clinical measurements. South African Journal of Food Science and Nutrition 1993; 5(4): 112-9.

11 Steyn NP, Burger S, Monyeki KD, Alberts M, Nthangeni G. Dietary Intake of the Adult Population of Dikgale 1998. Sovenga: University of the North, 1998.

12 Steyn NP, Burger S, Monyeki KD, Alberts M, Nthangeni G. Seasonal variation in the dietary intake of the adult population of Dikgale. South African Journal of Clinical Nutrition 2001; 14(4): 140-5.

13 Steyn NP, MacIntyre U, Olwagon R, Alberts M. Validation of multiple 24-hour recalls in a rural adult population using energy intake and estimated basal metabolic ratios. South African Journal of Epidemiology and Infection 2001; 16(1): 23-6. 
14 Bourne LT, Langenhoven ML, Steyn K, Jooste PL, Laubscher JA, Van der Vyfer E. Nutrient intake in the urban African population of the Cape Peninsula, South Africa. The BRISK Study. Central African Journal of Medicine 1993; 39(12): $238-47$.

15 Bourne LT, Langenhoven ML, Steyn K, Jooste PL, Laubscher JA. The food and meal pattern in the black population of the Cape Peninsula. The BRISK Study. Central African Journal of Medicine 1994; 40(6): 140-8.

16 Bourne LT, Langenhoven ML, Steyn K, Jooste PL, Laubscher JA, Bourne DE. Nutritional status of 3-6 year-old children in the Cape Peninsula. The BRISK Study. East African Medical Journal 1994; 7: 695-702.

17 Venter CS, MacIntyre UE, Vorster HH. The development and testing of a food portion photograph book for use in an African population. Journal of Human Nutrition and Dietetics 2000; 13: 205-18.

18 Vorster HH, Wissing MP, Venter CS, et al. The impact of urbanization on physical, physiological and mental health of Africans in the North West Province of South Africa: the THUSA study. South African Journal of Science 2000; 96 : 505-14.

19 MacIntyre UE, Venter CS, Vorster HH. A culture-sensitive quantitative food frequency questionnaire used in an African population: 1. Development and reproducibility. Public Health Nutrition 2000; 4(1): 53-62.

20 MacIntyre UE, Venter CS, Vorster HH. A culture-sensitive quantitative food frequency questionnaire used in an African population: 2. Relative validation by 7-day weighed records and biomarkers. Public Health Nutrition 2000; 4(1): 63-71.

21 MacIntyre UE, Venter CS, Vorster HH, Steyn HS. A combination of statistical methods for the analysis of the relative validation data of the quantitative food frequency questionnaire used in the THUSA study. Public Health Nutrition 2000; 4(1): 45-51.

22 MacIntyre EE, Kruger HS, Venter CS, Vorster HH. Dietary intakes of an African population in different stages of transition in the North West Province, South Africa: the THUSA study. Nutrition Research 2002; 22: 239-56.

23 Underhay C, de Ridder JH, van Rooyen JM, Kruger HS. The effect of urbanisation on the relationship between physical activity and obesity among 10-15 year-old children in the North West Province, South Africa: the THUSA study. Presented at The Southern Africa Congress of Sport Science, Stellenbosch, 5-9 November 2001.

24 Kruger HS, de Ridder JH, Pienaar AE. Overweight among children 10-15 years old in the North West Province: prevalence and associated factors [abstract]. Journal of Endocrinology, Metabolism and Diabetes of South Africa 2002; 7(1): 37.

25 Steyn NP, Senekal M, Brits S, Nel J. Urban and rural differences in dietary intake, weight status and nutrition knowledge of black female students. Asia Pacific Journal of Clinical Nutrition 2000; 9(1): 53-9.

26 Steyn NP, Senekal M, Brits S, Alberts M, Mashego T, Nel JH. Weight and health status of black female students. South African Medical Journal 2000; 90(2): 146-52.

27 Senekal M, Steyn NP, Mashego TA, Nel JH. Evaluation of body shape, eating disorders and weight management related parameters in black female students. South African Journal of Psychology 2001; 31: 45-53.

28 Senekal M, Steyn NP. Development of a Nutrition and Health Monitor. Sovenga: University of the North, 1997.

29 Senekal M, Steyn NP, Nel JH. Factors associated with overweight/obesity in economically active South African populations. Ethnicity and Disease 2003; 13: 109-15.

30 Wolmarans P, Langenhoven ML, Van Eck M, Swanepoel ASP. The contribution of different food groups to the energy, fat and fibre intake of the Coronary Risk Factor Study (CORIS) population. South African Medical Journal 1989; 75 167-71.

31 Steyn K, Fourie J, Benade AJ, Rossouw JE, Langenhoven ML, Joubert G, et al. Factors associated with high density lipoprotein cholesterol in a population with high high density lipoprotein cholesterol levels. Arteriosclerosis 1989; 9: $390-7$.

32 Steyn K, Steyn M, Swanepoel AS, Jordaan PC, Jooste PL, Fourie JM, et al. Twelve-year results of the Coronary Risk Factor Study (CORIS). International Journal of Epidemiology 1997; 26: 964-71.

33 Steyn NP, Abercrombie R, Labadarios D. Food security - an update for health professionals. South African Journal of Clinical Nutrition 2001; 14(3): 98-102.

34 Bourne LT. A liquid consumption survey of individuals in greater Cape Town. MSc Med (Community Health) thesis, University of Cape Town, 1986.

35 Food and Nutrition Board NAS-NRC (USA). Recommended Dietary Allowances, revised 1989. Journal of the American Dietetics Association 1989; 89: 1748-52.

36 Nel JH. Intakes of foods most commonly consumed: secondary data analyses of South African food consumption studies (1983-2000). MBA thesis, University of Stellenbosch, 2002.

37 Langenhoven ML, Kruger M, Gouws E, Faber M. Medical Research Council Food Composition Tables, 3rd ed. Parow: Research Institute for Nutritional Diseases, South African Medical Research Council, 1991.

38 Medical Research Council. Food Composition Tables [software]. Developed by the Nutrition Intervention Programme. Tygerberg: South African Medical Research Council, 1999.

39 Eurocode. Core Classification Version 99/2 [online]. Available at http://www.ianunwin.demon.co.uk/eurocode/ docmn/ec99/ecmg01ct.htm. Accessed 1 October 2001.

40 Central Statistical Services. Census '96. Pretoria: Central Statistical Services, 1999. 